\title{
Die pedagogie van inheemse kennis as sosiale konstruk
}

\begin{tabular}{|c|c|}
\hline \multicolumn{2}{|c|}{$\begin{array}{l}\text { Authors: } \\
\text { William J. Fraser }{ }^{1} \\
\text { Ronél Ferreira }{ }^{2}\end{array}$} \\
\hline \multicolumn{2}{|c|}{$\begin{array}{l}\text { Affiliations: } \\
{ }^{1} \text { Department of Science, } \\
\text { Mathematics and Technology } \\
\text { Education, University of } \\
\text { Pretoria, South Africa }\end{array}$} \\
\hline \multicolumn{2}{|c|}{$\begin{array}{l}{ }^{2} \text { Department of Educational } \\
\text { Psychology, University of } \\
\text { Pretoria, South Africa }\end{array}$} \\
\hline \multicolumn{2}{|c|}{$\begin{array}{l}\text { Correspondence to: } \\
\text { William Fraser }\end{array}$} \\
\hline \multicolumn{2}{|c|}{$\begin{array}{l}\text { Email: } \\
\text { william.fraser@up.ac.za }\end{array}$} \\
\hline \multicolumn{2}{|c|}{$\begin{array}{l}\text { Postal address: } \\
\text { Private Bag X20, Hatfield } \\
0028 \text {, South Africa }\end{array}$} \\
\hline \multicolumn{2}{|c|}{$\begin{array}{l}\text { Dates: } \\
\text { Received: } 08 \text { June } 2015 \\
\text { Accepted: } 03 \text { Aug. } 2015 \\
\text { Published: } 30 \text { Sept. } 2015\end{array}$} \\
\hline \multicolumn{2}{|c|}{$\begin{array}{l}\text { How to cite this article: } \\
\text { Fraser, W.J. \& Ferreira, R., } \\
\text { 2015, 'Die pedagogie van } \\
\text { inheemse kennis as sosiale } \\
\text { konstruk', Suid-Afrikaanse } \\
\text { Tydskrif vir Natuurwetenskap } \\
\text { en Tegnologie 34(1), Art. } \\
\text { \#1347, } 6 \text { pages. http:// } \\
\text { dx.doi.org/10.4102/satnt. } \\
\text { v34i1.1347 }\end{array}$} \\
\hline \multicolumn{2}{|c|}{$\begin{array}{l}\text { Copyright: } \\
\text { (C) 2015. The Authors. } \\
\text { Licensee: AOSIS } \\
\text { OpenJournals. This work is } \\
\text { licensed under the Creative } \\
\text { Commons Attribution } \\
\text { License. }\end{array}$} \\
\hline \multicolumn{2}{|l|}{ Read online: } \\
\hline 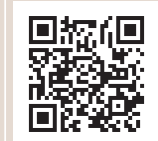 & $\begin{array}{l}\text { Scan this QR } \\
\text { code with your } \\
\text { smart phone or } \\
\text { mobile device } \\
\text { to read online. }\end{array}$ \\
\hline
\end{tabular}

In hierdie artikel word daar in die eerste plek gepoog om inheemse kennis as sosiale konstruk te verklaar, waarna die waarde daarvan vir die opvoedingspraktyk toegelig word. Inheemse kennis (IK) begrond dikwels leerders se eerste ervarings en verbind sodanige ervarings, deur spontane konsepvorming, met wetenskaplike verskynsels. IK dien ook as primêre leerorganiseerder vir verdere konseptualisering en skematisering. Die uitsluiting van inheemse kennis uit formele kurrikula is gewoonlik nie doelbewus nie, en die daadwerklike insluiting daarvan in leermateriaal kan 'n waardevolle bydrae lewer om as skakel tussen bestaande kennis en nuwe inligting te dien. Die erkenning van plaaslike bevolkings se inheemse kennis in kurrikula bemagtig nie net die kurrikuleerder nie, maar ook leerders wat op die inligting aangewese is. Aangesien inheemse kennis verweef is met die sosiale konstrukte van die samelewing, is deelnemende navorsingstrategieë gepas om hierdie kennis met die oog op kurrikulumontwikkeling te versamel, te kwantifiseer en te verifieer.

The pedagogy of indigenous knowledge as a social construct. This article explains indigenous knowledge, firstly as a social construct, and subsequently in terms of the value it holds for educational practice. Indigenous knowledge (IK) often constitutes the basis of learners' first experiences and links such experiences, via spontaneous conceptualisation, with scientific phenomena. IK also serves as the primary organiser of learning, with a view to further conceptualisation and schematisation. The exclusion of indigenous knowledge from formal curricula is usually not intentional, and its actual inclusion in learning material can make a valuable contribution towards linking existing knowledge and new information. The article claims that the indigenous knowledge of local populations should be acknowledged to empower curriculum developers and learners. Seeing that indigenous knowledge is interwoven with the social constructs of society, participatory research strategies are suggested to gather, quantify and verify information for curriculum development purposes.

Pedagogie: verwys na die opvoedingsmomente van 'n bepaalde verskynsel, of anders gestel, na die waarde wat dit tot die onderrig-leersituasie toevoeg. Dit impliseer dus die praktykwording van 'n verskynsel en die impak daarvan op leer. Vergelyk 'Pedagogy of the oppressed' of 'Pedagogie der Onderdrukten/Pedagogie van de onderdrukten'.

\section{Inleiding}

Die popularisering van inheemse kennis het vrae laat ontstaan na die relevansie van dié konstruk as besondere beskouing en faset van wetenskapbeskrywing, beide in terme van die waarde wat dit tot ons epistemologie van kennis toevoeg en die bruikbaarheid of toepaslikheid van die inligting. Verder bevraagteken dit ook die verrekening van inheemse kennis as kurrikuluminhoud. Die doel met hierdie betoog is nie om inheemse kennis as afsonderlike leksikon of besondere epistemologie - wat los staan van die huidige tradisionele Westerse beskrywing van bepaalde werklikhede - te verklaar en te vestig nie; dit is reeds gedoen (sien Le Grange 2004, 2007). Die doel is eerder om vanuit 'n bepaalde kurrikulerings- en navorsingsoogpunt lig te werp op die toeganklikheid van inheemse kennis as sosiale konstruk. Verskeie outeurs het veelmaals gepoog om inheemse kennis as wetenskap te begrond, en hierdie betoog wil inheemse kennis eerder as sosiale konstruk posisioneer deur die toeligting daarvan vanuit bepaalde postmoderne uitgangspunte (Doll 1993; Slattery 2006); kurrikuleringsdebatte (Carl 2009; Pinar 2004); bemagtigingintensies (Carl 2009); pragmatiese vertrekpunte (James 1948; Ornstein \& Hunkins 2009); en deelnemende ondersoekende aktiwiteite (Participatory Reflection and Action [Deelnemende Refleksie en Aksie]) (Chambers 1994a, 1994b). Siende dat alle leerervarings deel van formele en informele kurrikula uitmaak, is dit sinvol dat toepaslike inheemse kennis vir alle leerders deel van formele kurrikula moet wees. 


\section{Die reduksie van leerinhoud as kurrikuleringshandeling}

Kurrikula verteenwoordig die werklikheid. Daarom moet die inhouddaarvansógereduseerworddat'nverteenwoordigende seleksie van leerders se omgewing in die kurrikulum sal wees (Klafki 1964). Die werklikheidskategorieë waarna die skrywer verwys, sluit verskeie aspekte of komponente van die werklikheid in. Dit word tydens kurrikulering vanuit historiese, wetenskaplike, plantkundige, dierkundige, juridiese, kulturele en sosiale perspektiewe gereduseer, om 'n paar te noem. Klafki (1964) het die konstruk Kategorialen Bildung [Kategoriale vorming] geskep om te verduidelik hoe leerders hierdie verteenwoordigende primêre konsepte of boustene (elementare) moet gebruik om betekenis aan die werklikheid te gee. Bildungslehre of vormingsteorie beklemtoon die belangrikheid van spesifieke konstrukte wat tydens betekenisgewing deur leerders aangewend moet word. Dit beklemtoon die verband tussen Perquin (1964:99) se kultuur van sogenaamde 'vormingsgoed', Klafki se elementare, Ausubel (1968:507) se gebruik van advance organisers [primêre leerorganiseerders], en Piaget (1973:82) se 'objek' of voorbeeld. Hierdie eksemplare konstrueer Piaget se schema(ta) wat nou met die konstruk 'kennisstelsel' verband hou. Dit het die vraag laat ontstaan oor watter elementare, 'vormingsgoed' of konsepte by die kurrikulum ingesluit en uitgesluit behoort te word.

Christie (2008:172) gebruik begrippe soos kulturele en 'simboliese onreg' (onregverdigheid), 'kulturele dominasie', 'nie-erkenning' en 'disrespek' wanneer sy na historiese onreg verwys en reken dat erkenning noodsaaklik is om hierdie kulturele of sosiale onreg reg te stel. Haar argumente fokus onder meer op die uitsluiting van 'kultuurgoedere' uit 'n kurrikulum. Grant en Ladson-Billings (1997) reken ook die insluiting van diversiteit in die kurrikulum '... is motivated by the need to correct errors of omission ... related to ethnic and cultural diversity' [gemotiveer word deur 'n behoefte om foute van uitsluiting wat met etniese en kulturele diversiteit verband hou, reg te stel]. Dit is egter 'n ope vraag of die insluiting of uitsluiting (positiewe of negatiewe erkenning) van inheemse kennis in 'n kurrikulum polities of kultureel (sosio-ekonomies) gedrewe is of was, en of die beskikbaarheid van relevante materiaal en voorbeelde, hetsy vanweë onkunde of intensioneel, ontoeganklik vir kurrikuleerders geword het. Volgens De Beer en Van Wyk (2012:2) sien lewenswetenskappe-onderwysers wel die belangrikheid van inheemse kennis in, maar is hul kundigheid gebrekkig om inheemse kennis deel van die kurrikulum te maak.

Wat is gevolglik die verband tussen die sosio-ekonomiese status van ' $n$ individu/gemeenskap en die aanvaarding van die individu/gemeenskap se kultuurgoedere of 'vormingsgoed' vir kurrikulering? Het minderheidsgroepe of gemarginaliseerde meerderheidsgroepe enige sê in die kurrikulering van leerinhoude? Staan inheemse kennis onafhanklik as gevestigde bron van lewenswetenskaplike kennis, of kan dit as essensiële voorkennis en leerorganiseerders vir betekenisvolle leer geakkommodeer en geassimileer word? Slattery (2006) vat die waarde van voorkennis treffend saam:

prior experience as a legitimate source of knowledge construction in schools and classrooms allows us to think about education as life process rather than a static set of information or procedures ... [... voorkennis as 'n geldige bron van kennissamestelling in skole en klaskamers laat ons toe om opvoeding as 'n lewensproses te beskou, eerder as ' $n$ statiese stel inligting of prosedures ...]. (p. 81, [Outeur se eie vertaling])

\section{Kurrikulum, kurrikulering en kurrikulumnavorsing as sosiale konstrukte}

Doll(1993:127)verwysna'nsogenaamdecurrere-georiënteerde kurrikulum as 'n kurrikulum wat kultuur beklemtoon deur verwysingsraamwerke te skep waar individuele en openbare (publieke) refleksies verreken wie ons is, wat ons doen en waarom ons bepaalde handelinge uitvoer. Currere en curro is gegrond op die 'lewenswedloop' en 'voorbereiding' vir hierdie wedloop as metafoor (Carl 2009:27; Marsh \& Willis 1999:7; Pinar 2004:35; Van den Akker, Kuiper \& Hameyer 2003:2). Vir Pinar (2004:35) verskaf kurrikulum '... a strategy for students of curriculum to study the relations between academic knowledge and life history in the interest of self-understanding and social reconstruction' [... 'n strategie vir studente om die verband tussen akademiese kennis en lewensgeskiedenis in belang van selfbegrip en sosiale rekonstruksie te bestudeer]. Indien 'n demokratiese skool gedefinieer kan word as 'n skool waar almal gelyke geleentheid tot besluitneming het (Beane \& Apple 1995:9), kan 'n demokratiese kurrikulum en demokratiese kurrikulering gesien word as 'n kurrikulum waar almal die geleentheid gehad het om tot die kurrikulum en kurrikulering by te dra. In die laat tagtigs het 'n wêreldwye beweging, People's Education [Opvoeding vir die Mense] tot stand gekom, wat juis hierdie beginsel ten doel gehad het en dit ook aktief uitgebou het. Pogings is aangewend om 'n balans tussen Westerse en Afrika-inhoud te vind (Holdstock 1987:18), terwyl gemeenskappe self besluit het watter en hoe hierdie inhoude bemeester moet word. Onwu en Mosimege (2012) in De Beer en Van Wyk (2012:3) waarsku egter dat 'dit 'n fout sou wees om inheemse kennis aan dieselfde verifikasieprosedures te onderwerp as in die geval van moderne wetenskap'. Die diversifisering van kurrikula tot gemeenskapsbesit het die waarde van 'n kurrikulum as sosiale konstruk beklemtoon.

\section{'n Krities pragmatiese beskouing van kurrikulering}

In 'n verwysing na Lather, versoek Slattery (2006:27) 'n dekonstruksie van die betekenis van kurrikulum (en derhalwe ook die kurrikuluminhoude wat as leerinhoud in leerplanne figureer - outeur se eie toevoeging) deur 'n evaluering van die 'unequal power relations' [ongelyke magsverhoudinge] waar studente 'subordinate and submissive' [onderhorig en onderdanig] teenoor onderwysers moet staan. Studente en 
onderwysers moet gevolglik bevry word van die gevolge van so 'n outoritêre kurrikulum. Maar wanneer word ' $n$ kurrikulum en kurrikulering outoritêr? Lê die outoritêre mandaat van 'n kurrikulum in die voorskriftelikheid van die kurrikuluminhoud, of ook in die filosofiese onderbou wat die kurrikulum begrond en verteenwoordig? Verskeie outeurs verreken inhoud, ideologie en filosofie tydens kurrikulering en beskryf die handeling as benadering tot kurrikulering (Carl 2009; Lovat \& Smith 2003; Marsh \& Willis 1999; Ornstein \& Hunkins 2009).

In die tyd waarin ons leef, kan 'n krities pragmatiese (eksperimentalistiese) onderbou tot kurrikulering moeilik van postmoderne uitgangspunte losgemaak word. Die postmodernisme poog juis om relevant, kontemporêr, toepaslik, divers en allesinsluitend tot kurrikulumontwikkeling by te dra. Of anders gestel, 'n postmoderne kurrikuleerder sal sekerlik 'n kurrikulum wil ontwikkel wat die behoeftes en ervarings van diverse leerders en 'n diverse samelewing in aanmerking sal neem. In antwoord op die vraag oor wat kurrikulumteorie behels, skryf Pinar (2004:2) baie duidelik '... curriculum theory is the interdisciplinary study of educational experience' [kurrikulumteorie is die interdissiplinêre studie van opvoedkundige ervaring]. Hierdie uitgangspunt som een van die klassieke definisies van kurrikulum treffend op: Kurrikulum is al die leerervarings van leerders (Carl 2009: 28-29). Ek verwys later weer na hierdie aanname wanneer voorkennis as vereiste vir effektiewe onderrig en leer ter sprake kom. Daar kan egter met Marsh en Willis (1999:41) saamgestem word dat ' $n$ enkele benadering nie die antwoord tot kurrikulering is nie. James, een van die grondleggers van die pragmatisme, was van mening dat idees waar word net sover hulle ons in staat stel om bevredigende verhoudings met die res van ons ervarings aan te gaan' (Speake 1979:284). Smith en Ragan (1999:17) is baie duidelik hieroor: '... pragmatists ... believe that knowledge is interpreted through reason and is temporary and tentative' [pragmatiste ... glo dat kennis deur rede geïnterpreteer word en \{dus\} tydelik en tentatief is]. En verder (bl. 18) '... [ $p$ ] ragmatists suggest that knowledge in a particular field is negotiated based upon an agreement of experts as to a common interpretation of experience'. [Pragmatiste stel voor dat kennis in 'n spesifieke veld onderhandel word op grond van 'n ooreenkoms tussen kundiges, gebaseer op 'n gemeenskaplike interpretasie van ervaring]. Dit was dan ook hierdie beskouing van 'ervaring' wat Dewey se siening van progressiewe funksionalisme onderskryf het (Glatthorn, Boschee \& Whitehead 2006:39). Maar pragmatiste sal ook (soos later in hierdie artikel uiteengesit gaan word) voorskriftelik wees ten opsigte van die spoedige en tydige generasie van bruikbare inligting. Chambers (1994a:) laat hom soos volg daaroor uit:

In conditions of faster change and of increasing unpredictability, it is even more important than before to have timely feedback, prompt learning, and rapid adaptive responses which will differ to fit local contexts. [In omstandighede van vinniger verandering en toenemende onvoorspelbaarheid is dit selfs belangriker as tevore om tydige terugvoering, vinnige leer en spoedige aanpasbare response te hê wat sal verskil om by plaaslike kontekste te pas]. (p. 1449, [Outeur se eie vertaling])

Die leerervarings soos hier bo na verwys, moes egter aan spesifieke kriteria voldoen het. Dit moes demokraties wees, ontwikkeling bevorder en vir die leerder geleentheid bied om betekenis te skep. Ornstein en Hunkins (2009:36) beklemtoon dat ons gevestigde veralgemenings heel dikwels die enigste riglyne is wat ons het om met die sosiale omgewing te integreer. Om hieraan te kan voldoen, moet onderwys meer ondersoekend as verklarend wees (Ornstein \& Hunkins 2009:36). As 'n teorie van waarheid wat voortdurend verander, huisves dit sterk positivistiese ondertone. Dit is dan verstaanbaar waarom die pragmatisme 'n demokratiese en sosiaal aanvaarbare bestel ten doel gehad het en steeds het. James (1948:142) sien die pragmatiese metode juis as 'n werkswyse om metafisiese geskille (soos byvoorbeeld die bevraagtekening na inheemse kennis as volwaardige wetenskapsterrein) te verken en te verreken. Die feit dat inheemse kennis nie noodwendig die werklikheid probeer verklaar deur dit (in positivistiese of postpositivistiese konteks - outeur se eie toevoeging) tot onmiddellike gevolge te reduseer nie (De Beer \& Van Wyk 2012:2), plaas die verrekening van inheemse kennis as sosiale konstruk nader aan 'n postmoderne en kritiese werklikheidsbeskouing.

\section{Enkele benaderings tot die ontsluiting van inheemse kennis Oriëntering}

Kurrikula word uit substans (inhoud) en sintaks (prosesse) saamgestel (Carl 2009:32; Doll 1993:13; Ornstein \& Hunkins 2009:217; Van den Akker et al. 2003:4). Substans verklaar die inhoude, terme, begrippe, konsepte, reëls en wette, terwyl die sintaks die prosesse of aktiwiteite uiteensit wat nodig is om substans bloot te stel.

Carl (2009) lê sterk klem op die bemagtiging van onderwysers as potensiële kurrikuleerders. Alhoewel hierdie bemagtiging hoofsaaklik op klaskameraktiwiteite toegespits is, bestaan daar tog 'n behoefte om die kundigheid van onderwysers op makrovlak te benut. Onderwyservakverbonde en onderwyskundiges pleit al vir 'n geruime tyd dat onderwysers toegelaat moet word om aan nasionale (makro) kurrikuleringshandelinge deel te neem. Weens die sogenaamde 'onkundigheid' van onderwysers en die monopolie van die regering het daar tot op datum nie veel hiervan gekom nie. Onderwyserimpak soos deur die Departement van Hoër Onderwys en Opleiding (2011) gevisualiseer, word tot die klaskamer beperk.

Chambers (1994a) gebruik die term 'professional possessiveness' [professionele besitlikheid] om die uitsluiting van die plaaslike gemeenskap uit besluitneming te beklemtoon. Die kundigheid om besluite oor kurrikuluminsluiting te neem, lê gevolglik nie langer net by politieke besluitnemers, kurrikuleerders en akademici nie. Bemagtiging raak twee aspekte aan. In die eerste plek bied dit onderwysers die 
geleentheid om direk by kurrikulering betrokke te raak en om, onder meer, persoonlike insette ter verbetering van kurrikula te lewer. Tweedens bemagtig dit onderwysers omdat dit 'n 'gevoel van waarde' by deelnemers tuisbring. Een van die doelstellings van 'n navorsingsmetodologie, aanvanklik bekend as Participatory Rural Appraisal (PRA) [Deelnemende Landelike Beoordeling \{DLB\}], nou Participatory Reflection and Action [Deelnemende Refleksie en Aksie $\{\mathrm{DRA}\}$ - later meer hieroor], is juis om deelnemers toe te laat om eienaarskap te neem en self besluite te neem en uitdagings aan te pak (Chambers 1994a:1444). Dit voeg waarde toe tot deelnemers se kundigheid en kennis, en spreek waardering uit vir hul bydrae tot aspekte van plaaslike en nasionale belang. Hierdie werkswyse is met groot sukses deur plaaslike bevolkings van ontwikkelende lande aangebied met die doel om die insette, ervarings en mening van die bevolking oor belangrike sake in te win. Deur PRA as navorsingsbenadering en/of datainsamelingstrategie te gebruik, kan deelnemers se kennis rakende kurrikuluminhoude ingesamel word. Daar sal later in hierdie artikel weer na hierdie strategie verwys word.

McKernan, in Short (1991:309), gebruik die konstruk Action Inquiry [aksie-ondersoek] om te illustreer hoe variasies van aksienavorsing - en dan wel kurrikulum-aksienavorsing 'n bruikbare strategie kan word om spesifiek meer van die kurrikuleringspraktyk te wete te kom. Hy beweer dat action enactment of aktiewe deelname (aktiewe belewing) onderhewig is aan ongedwonge dialoog (ideale dialoog, soos Habermas dit stel) wat as voorwaarde tot probleemoplossing in 'n kurrikulum gereken kan word. Carr en Kemmis (1986), in McKay en Romm (1992:90) beaam dat hierdie dialectical view of reality [dialektiese beskouing van die werklikheid] 'n belangrike kriterium vir aksienavorsing is. Hoadley en Jansen (2009:258) skrywe dat dialoog kritiese refleksie tydens kurrikulering van beide onderwyser en leerder vereis. Die skrywers bevestig (bl. 259) dat '... curriculum planning is not viewed as a technical matter, but instead as a political and ideological matter' [kurrikulumbeplanning nie as 'n tegniese, maar eerder as 'n politieke en ideologiese saak gesien word]. Short (1991:315) beveel 'n werkswyse aan wat die klassieke navorsingstappe naboots, buiten dat die ontwikkeling van 'n aksieplan, sowel as die implementering daarvan, ooreenkomste met aksienavorsing toon. Robert Chambers (1994a:1437) daarenteen dui in 'n oorsigartikel aan hoe dat 'n voorsetting van klassieke aksienavorsing te wete Participatory Rural Appraisal [Deelnemende Landelike/ Plattelandse Beoordeling] (PRA) deur die jare ontwikkel het as ' $n$ navorsingstrategie om plaaslike bevolkings die geleentheid te bied om hul 'lewenskennis en omstandighede' te deel, te 'bevorder,' te 'analiseer' en 'daarop te reageer'.

Chambers (1994b:963) som die situasie soos volg op: 'Agricultural scientists, medical staff, teachers, officials, extension agents and others have believed that their knowledge was superior and that the knowledge of farmers and other local people was inferior ...' [Landboukundiges, mediese personeel, onderwysers, amptenare, voorligtingsbeamptes en ander het geglo dat hul kennis meerderwaardig was, en dat die kennis van boere en ander plaaslike mense minderwaardig is]. Chambers (1994b:963) gebruik die term past ignorance of 'historiese onkunde' om sy argument te staaf. Chambers (1994a:1445) kom verder met' $n$ interessante stelling na vore deur te beweer dat plaaslike mense 'tot iets in staat is' totdat die teendeel bewys is! Die klem val gevolglik op individuele beoordeling. Dit is die stem van die plaaslike bevolking wat tel, en nie noodwendig die geskrewe reëls, regulasies en vasgestelde prosedures van 'geykte navorsingsmetodes' nie (Chambers 1994a:1450). Die plaaslike bevolking is die eksperts of 'ingeligtes' binne hulle spesifieke konteks, en dit is juis in hulle wat die antwoorde op konteksspesifieke vraagstukke opgesluit lê. Alternatiewe navorsingsmetodes is derhalwe ontwikkel om die inheemse kennis van plaaslike bevolkings te bekom (Von Maltzahn \& Van der Riet 2006). Die praktiese aanwending van DRA as data-insamelingstrategie word vervolgens in die konteks van kurrikulum-aksienavorsing toegelig.

\section{Deelnemende Landelike Beoordeling [Participatory Rural Appraisal] en Deelnemende Refleksie en Aksie [Participatory Reflection and Action]}

In die eerste gevallestudie het De Beer en Van Wyk (2011) en Van Wyk en De Beer (2012) die benutting van bruikbare plante onder die Khoi en San nagevors deur van 'n DLBmetodologie gebruik te maak. Tradisionele (inheemse) kennis is by deelnemers ingewin. Hierdie navorsers se besorgdheid oor die geldigheid wat dikwels met DBLmetodes verband hou, het bygedra tot hul wysiging van Von Maltzahn en Van der Riet (2006) se sogenaamde 'matrix ranking' [matriksrangordening]. Laasgenoemde navorsers sou byvoorbeeld 'n ruit aan deelnemers voorsien, die doel daarvan verduidelik en van deelnemers verwag om die ruit met inligting te voltooi. De Beer en Van Wyk (2011:743) se daaropvolgende nuut ontwikkelde matriksmetodes dien soortgelyke funksies. In die eerste plek kwantifiseer hulle die etnobotaniese kennis van deelnemers, lys en groepeer die inligting, en kwantifiseer die akkuraatheid van die inligting teen 'n stel geverifieerde kriteria sodat elke deelnemer se etnobotaniese kennisindeks bereken kan word. Die belangrikheid en populariteit van elke plantspesie vir die individuele deelnemers wat aan die studie deelgeneem het, kon vervolgens bepaal word (bl. 751). In die tweede plek kon die versamelde inligting met die kundighede van etnobotaniste getrianguleer word om die herhaalbaarheid van predominante plante in terme van voorkoms en funksie kollektief te bereken. 'n Spesiesgewildheidsindeks (SGI) is vir hierdie doel ontwikkel.

Bogenoemde data-insamelingstrategieë staaf die bruikbaarheid van deelnemende aksienavorsingsinisiatiewe om inheemse kennis vir kurrikuleringsdoeleindes van plaaslike bevolkings te bekom, terwyl die indeksering van sodanige inligting die verdere verifiëring of geldigheid van die inligting staaf. In die tweede en derde gevallestudies fokus navorsers nie direk op die verhaling van inheemse kennis uit plaaslike bevolkings nie, maar hulle pas dieselfde navorsingstrategieë toe om plaaslike inligting in die eerste plek te onttrek, en tweedens onder die navorsers se aandag te bring. 
Ferreira et al. (2014), Fraser et al. (2013), en Fraser et al. (2015) illustreer hoedat DRA as navorsingstrategie aangewend word om praktykgebaseerde kennis uit gemeenskappe te onttrek en te verreken. In die tweede geval werk navorsers saam met ouers en onderwysers om te bepaal (1) watter voedselbronne deur ouers benut word, (2) hoe voedsel voorberei word en (3) wanneer die voedsel benut word. Beide gevallestudies het DRA as navorsingsmetode toegepas soos deur Ferreira voorgestel, gebaseer op haar navorsing in gemeenskappe arm aan hulpbronne waar kwesbare individue uitdagings soos armoede en HIV en Vigs-verwante probleme moet hanteer (Ferreira 2007, 2008, 2013). Die basiese proses sluit, onder meer, behoeftebepaling en situasie-analise in - twee aktiwiteite wat met kurrikulering en kurrikulumontwikkeling verweef is. Die inligting wat hieruit bekom is, kon gevolglik suksesvol aangewend word om skoolkurrikula vir gemeenskapsbemagtiging uit te brei.

In die laaste scenario het ongeveer 400 finalejaaronderwysstudente 'n DRA-strategie in groepe toegepas en die volgende op matrikse aangedui: (1) die eienskappe van ideale onderwysers ten opsigte van kennisverwerwing, onderrigstrategieë, studente-ondersteuning en professionele ontwikkeling, (2) bronne waaruit inligting bekom kan word vir die verdere ontwikkeling van 'n onderwyseridentiteit en (3) aksieplanne wat studente in plek kan plaas om tekortkominge en leemtes aan te vul, wat weer eens die potensiële waarde beklemtoon van 'n benadering waar deelnemers eienaarskap neem van die uitdagings wat hulle in die gesig staar. Uit hierdie Gemeenskaplike Praktyk, of Community of Practice soos Wenger (1998) dit stel, versamel studente ervarings wat tot die ontwikkeling van hul onderwyseridentiteit sal bydra (Beauchamp \& Thomas 2009). 'n Mens sou kon saamstem dat die inligting wat studente in hierdie geval ingesamel het, nie noodwendig klassieke inheemse kennis was nie, maar dat dit praktykgevestigde professionele kundighede is wat onderwyser-identiteit vestig. Hierdie standpunt onderskryf Vygotsky se beskouing van spontane konsepvorming konsepte wat spontaan ontwikkel, namate leerders daagliks aan die kulturele omgewing blootgestel word.

Vygotsky (2012:xviii) het naamlik aangedui dat spontane konsepvorming wat daagliks plaasvind (byvoorbeeld die feit dat die son opkom), beduidend verskil van die feite wat op skool geleer word (roterende aarde as die oorsaak van dag- en nagwisseling). Voorskoolse leerervaring (spontane konsepvorming) verskil dus van die assimilasie van wetenskaplike kennis op skool (Vygotsky 1978:84). Dog onderwysers beskik oor praktiese wysheid (fronese) of prudence - 'n wysheid wat noodsaaklik is vir die ontwikkeling en instandhouding van 'n eie praktykteorie (Korthagen \& Kessels 1999). Indien inheemse of tradisionele kennis dan ook as 'praktiese wysheid' gereken kan word, kan sterk ooreenkomste tussen inheemse kennis en professionele kennis gevind word. Die gevallestudies waarna daar hier bo verwys word, het drie aspekte gemeen: Die aktiwiteite fokus op daaglikse handelinge soos voedselproduksie, voedselverkryging, voedselbenutting, onderrig, professionele en identiteitsontwikkeling; dit vind in gemeenskaplike praktyke plaas; en dit genereer inligting en kennis wat deur lede van die gemeenskap gedeel en geverifieer word.

Die afleiding kan gevolglik gemaak word dat gemeenskapsgebaseerde navorsingsmetodes (soos DLB en DRA) geskik is om inheemse kennis en vakkennis te onttrek en vir kurrikulering beskikbaar te stel. Die belangrikheid en geloofwaardigheid van die inligting kan gekontroleer word deur verskillende deelnemers se inligting aan te teken en met dié van ander te vergelyk. Die geloofwaardigheid van die inligting lê meestal in die praktiese doeltreffendheid van die ingesamelde kennis en nie noodwendig in die wetenskaplike verklaring daarvan nie.

\section{Gevolgtrekking}

Gemeenskapspraktyke stel mense aan verskeie aktiwiteite bloot. Hierdie handelinge kan eenvoudig of ingewikkeld wees, maar verwag dikwels van individue geykte en beproefde vaardighede om die aktiwiteite suksesvol te voltooi. In baie gevalle is die kennis nie noodwendig in formele kurrikula verreken om dit tydens onderrig onder die aandag van leerders te bring nie, maar lê dit opgesluit in tradisionele praktyke wat met die verloop van tyd effektief aangewend is om aan ' $n$ bepaalde behoefte te voldoen.

Hetsy dit nou 'algemene' of 'inheemse' kennis is, hierdie kennis is dikwels 'gemeenskapsbesit' of 'praktykbesit' met gevestigde sosiale skakels, reëls en beginsels wat die toepassing en nakoming daarvan moontlik kan voorskryf. As sosiale konstruk ontwikkel dit spontaan tot primêre konsepte wat grotendeels vir die uitbouing van skemas en stelsels verantwoordelik is. Dit is dikwels leerders se eerste inleiding tot wetenskapsverifiëring en -substansiëring. Deelnemende refleksies (dialoog) en aksies het toonaangewende strategieë geword om aan lede die geleentheid te bied om inheemse en algemene kennis met mekaar te deel. Die konsensus oor die waarde wat inheemse kennis tot 'n bepaalde funksie toevoeg, dra by tot die geloofwaardigheid van die inligting wat op hierdie wyse bekom word.

Wanneer benaderings soos DRA gevolg word om uitdagings aan te pak, kry lede van die gemeenskap dus die geleentheid om hulle kennis en ervaring aan te wend en self tot oplossings te kom. Op dié wyse kan individue of groepe mense op hulle repertoire van inheemse kennis steun om hulself en hul gemeenskap (hetsy kollegas in hulle wêreld van werk of lede van die gemeenskap waar hulle woon) uit te bou of te versterk. Dit volg dat sodanige oplossings tot konteksspesifieke probleme 'n sterker moontlikheid van volhoubare oplossings impliseer, aangesien hierdie lede in sulke gevalle eienaarskap sal neem en self die handelinge tot oplossings sal bestuur, gedryf deur hulle belewing van bemagtiging om dit te kan doen, met inisiatiewe gesetel in kollektiewe inheemse kennis en ervaring. Verder lei so 'n benadering uiteraard daartoe dat die kollektiewe inheemse kennisbasis in die spesifieke 
gemeenskap of werksgemeenskap verder versterk sal word. Op hierdie wyse kan inheemse kennis as sosiale konstruk of uitvloeisel van sosiale aksies - beskou word.

\section{Erkenning Mededingende belange}

Die outeurs verklaar dat hulle geen finansiële of persoonlike verhouding(s) het wat hulle op 'n voordelige of nadelige wyse in die skryf van die artikel beïnvloed het nie.

\section{Outeursbydrae}

W.J.F. (Universiteit van Pretoria) was volledig verantwoordelik vir die konseptualisering, ontwerp en gedeeltelike skrywe van hierdie artikel. R.F. (Universiteit van Pretoria) het DRA as navorsingsmetode verfyn en in twee van die gevallestudies gebruik. Sy het insette gelewer by die afdelings wat handel oor die toepassing van DRA en die potensiaal daarvan in die uitbou van 'n inheemse kennisbasis.

\section{Literatuurverwysings}

Ausubel, D.P., 1968, Educational psychology. A cognitive view, Holt, Rinehart \& Winston, New York.

Beane, J.A. \& Apple, M.W. (eds.), 1995, Democratic schools, Association for Supervision and Curriculum Development, Alexandria, VA.

Beauchamp, C. \& Thomas, L., 2009, 'Understanding teacher identity: An overview of issues in the literature and implications for teacher education Cambridge Journal of Education 39(2), 175-189. http://dx.doi.org/10.1080/ 03057640902902252

Carl, A.E., 2009, Teacher empowerment through curriculum development, 3rd edn., Juta and Company, Cape Town.

Chambers, R., 1994a, 'Participatory rural appraisal (PRA): Challenges, potentials and paradigm', World Development 22(10), 1437-1454. http://dx.doi. org/10.1016/0305-750X(94)90030-2

Chambers, R., 1994b, 'The origins and practice of participatory rural appraisal', World Development 22(7), 953-969. http://dx.doi.org/10.1016/0305-750X(94) World Dever-4

Christie, P., 2008, Opening the doors of learning. Changing schools in South Africa, Heinemann, Sandton.

De Beer, J.J.J. \& Van Wyk, B.-E., 2011, 'An ethnobotanical survey of the Agter-Hantam, Northern Cape Province, South Africa', South African Journal of Botany 77, 741754. http://dx.doi.org/10.1016/j.sajb.2011.03.013

De Beer, J.J. \& Van Wyk, B-E., 2012, 'Inheemse Kennis in die lewenswetenskappeklaskamer: Wetenskap, pseudo-wetenskap, of 'n vermiste skakel?', SuidAfrikaanse Tydskrif vir Natuurwetenskap en Tegnologie 31(1), Art. \#368, 5 bladsye. http://dx.doi.org/10.4102/satnt.v31i1.368

Department of Higher Education and Training, 2011, 'The minimum requirements for teacher education qualifications', Government Gazette No. 34467, 1-64.

Doll, W.E., 1993, A post-modern perspective on curriculum, Teachers' College Press, New York.

Ferreira, R., 2007, 'Community-based coping: An HIV-AIDS case study', in N. Duncan, A. Naidoo, J. Pillay \& Roos (eds.), Analysis, context and action: An introduction to community psychology, pp. 380-391, Juta, Cape Town.

Ferreira, R., 2008, 'Using intervention research to facilitate community-based coping with HIV\&AIDS', in L. Ebersöhn (ed.), From microscope to kaleidoscope: Reconsidering psychosocial and educational aspects related to children in the HIV\&AIDS pandemic, pp. 85-100, Sense Publishers, Rotterdam.

Ferreira, R., 2013, 'Asset-based coping as one way of dealing with vulnerability', in M. Wissing (ed.), Well-being research in South Africa, pp. 415-438, Springer-Verlag, Heidelberg.
Ferreira, R., Fraser, W.J., Botha, K., du Toit, P. \& Gericke, G., 2014, 'Teachers' and parents' voices as building blocks of a health-promoting intervention in a vulnerable community', referaat aangebied by die Een-en-twintigste Internasionale Kongres community', referaat aangebied by die Een-en-twintigste Internasionale Kongres York, 14-17 Julie.

Fraser, W.J., Ferreira, R., De Villiers, R., Botha, K., Cook, E. \& Kumalo, D., 2013, 'Food choice, food production and food consumption at school and in the Life Sciences school curriculum', referaat aangebied by die jaarlikse ISTE-Konferensie van die Universiteit van Suid-Afrika, Mopaniekamp, Kruger Nasionale Park, 21-25 Oktober.

Fraser, W., Ferreira, R., Kazeni, M., Beukes, L.D. \& Eberlein, E., 2015, 'Student teachers as researchers: Developing teacher identities in a community of practice', referaat aangebied by die jaarlikse EduLearn15 Konferensie, Barcelona, Spanje, 06-08 Julie.

Glatthorn, A.A., Boschee, F. \& Whitehead, B.M., 2006, Curriculum leadership. Development and implementation, SAGE, Thousand Oaks, CA.

Grant, C.A. \& Ladson-Billings, G. (eds.), 1997, Dictionary of multicultural education, Oryx Press, Phoenix, AZ.

Hoadley, U. \& Jansen, J., 2009, Curriculum. Organising knowledge for the classroom, 2nd edn., Oxford University Press, Cape Town.

Holdstock, L., 1987, Education for a new nation, Media House, Sandton.

James, W., 1948, Essays in pragmatism, Hafner, New York.

Klafki, W., 1964, Das pädagogische Problem des Elementaren und die Theorie der kategorialen Bildung, Verlag Julius Beltz, Weinheim.

Korthagen, F.A.J. \& Kessels, J.P.A.M., 1999, 'Linking theory and practice: Changing the pedagogy of teacher education', Educational Researcher 28(4), 4-17. http:// dx.doi.org/10.3102/0013189X028004004

Le Grange, L., 2004, 'Western science and indigenous knowledge: Competing perspectives or complementary frameworks?' South African Journal of Higher Education 18(3), 82-91.

Le Grange, L., 2007, 'Integrating Western and indigenous knowledge systems: The basis for effective science education in South Africa?' International Review of Education 53, 577-591. http://dx.doi.org/10.1007/s11159-007-9056-x

Lovat, T.J. \& Smith, D.L., 2003, Curriculum. Action on reflection, 4th edn., Social Sciences Press, Tuggerah, AUS.

Marsh, C.J. \& Willis, G., 1999, Curriculum. Alternative approaches, ongoing issues, 2nd edn., Prentice-Hall, Upper Saddle River.

McKay, V.I. \& Romm, N.R.A., 1992, People's education in theoretical perspective, Maskew Miller Longman, Cape Town.

Ornstein, A.C. \& Hunkins, F.P., 2009, Curriculum foundations, principles, and issues, 5 th edn., Pearson International, Boston, MA.

Perquin, N., 1964, Algemene Didactiek, J.J. Romen \& Zonen, Uitgevers, RoermondMaaseik, Holland.

Piaget, J., 1973, The child and reality. Problems of genetic psychology, Frederick Muller, London.

Pinar, W.F., 2004, What is curriculum theory? Lawrence Erlbaum Associates, Mahwah.

Short, E.C. (ed.), 1991, Forms of curriculum inquiry, State University of New York Press, Albany.

Slattery, P., 2006, Curriculum development in the postmodern era, 2nd edn., Routledge, Taylor \& Francis Group, New York.

Smith, P.L. \& Ragan, T.J., 1999, Instructional design, 2nd edn., John Wily \& Sons, Hoboken, NJ.

Speake, J. (ed.), 1979, A dictionary of philosophy, Pan Books, London.

Van den Akker, J., Kuiper, W. \& Hameyer, U., 2003, Curriculum landscapes and trends, Kluwer Academic, Dordrecht.

Van Wyk, B-E. \& De Beer, J.J., 2012, 'Sosiaalaanspreeklike etnobotaniese opnames in die Kaapse flora: Etiese beginsels, metodologie en kwantifisering van data', SuidAfrikaanse Tydskrif vir Natuurwetenskap en Tegnologie 31(1), Art. \#369, 8 bladsye. http://dx.doi.org/10.4102/satnt.v31i1.369

Von Maltzahn, R. \& Van der Riet, T., 2006, 'A critical reflection on participatory methods as an alternative mode of enquiry', New Voices in Psychology 2(1), 108-128.

Vygotsky, L.S., 1978, Mind in society. The development of higher psychological processes, edited by M. Cole, V. John-Steiner, S. Scribner, \& E. Souberman, Harvard University Press, Cambridge.

Vygotsky, L.S, 2012, Thought and language, revised and expanded edition, edited and translated by E. Hanfmann, G. Vakar, \& A. Kozulin, MIT Press, Cambridge.

Wenger, E., 1998, Community of practice, viewed 10 April 2015, from http://www. leerarchitectuur.nl/wp-content/uploads/2013/03/Wenger_Coenders_artikel-uitCanon-vh-Leren.pdf 